\title{
Glioblastoma - Current Concepts, Prognostic Markers And Molecular Classification
}

\author{
Arvids Jakovlevs*, Andrejs Vanags**, Dainis Balodis*, Janis Gardovskis**, Ilze Strumfa* \\ * Department of Pathology, Riga Stradins University, Latvia \\ ** Department of Surgery, Riga Stradins University, Latvia
}

\begin{abstract}
Summary
Glioblastoma (GBM) has very poor prognosis despite aggressive therapy including surgical treatment. At present, few molecular markers could clarify GBM prognosis in greater detail. However, better understanding of the molecular pathogenesis would be the mainstay of improved, more personalized treatment modalities. Recent large-scale molecular studies brought new data that altered previous concepts about GBM; even molecular subtypes of GBM have been discovered. We discuss here the classic pathology of GBM along with molecular markers and subtypes of GBM as well as routine applications of these advances.

Key words: Glioblastoma, molecular subtypes, prognostic markers.
\end{abstract}

\section{INTRODUCTION}

Glioblastoma (GBM) is one of the most common and aggressive tumours of central nervous system (CNS). It represents the highest grade (grade IV) of glioma. Despite the standard therapy with maximal possible surgical resection, followed by radiotherapy and chemotherapy with temozolamide, the prognosis of GBM patients remains dismal, with the median survival of $12-15$ months (33). Better understanding of pathogenesis and underlying molecular abnormalities is essential to develop more effective targeted therapy. Over the last years, few large-scale genomic profiling studies discovered the molecular subtypes GBM $(34,28,15,19)$. To date, increasing amount of molecular prognostic factors has been described for GBM, but there are many controversies regarding their role.

The aim of the article is to describe recent advantages in the molecular characteristics of glioblastoma and to highlight the corresponding current concepts with regard to clinical implications and prognostic role.

\section{Overview of glioblastoma treatment}

Despite tremendous research efforts, few therapeutic options exist for GBM. The standard therapy includes maximal surgical resection followed by radiotherapy and chemotherapy with temozolamide (33). Total resection of GBM is not possible due to highly infiltrative growth pattern of this tumour so residual neoplastic cells give rise to recurrences in almost all cases. Comparing with other solid malignancies little progress is reached in the treatment of GBM.

\section{Classic pathology of glioblastoma}

In daily practice, typing and grading of gliomas is based on microscopic evaluation of haematoxylin and eosinstained histological specimens. P.Bailey and H.Cushing provided the framework of the morphological classification of CNS tumours. This concept was based on similarity between tumour cells and non-neoplastic glial cells. At present, it still forms the basis of the latest WHO classification of glial tumours $(2,17)$. In the 1940 s,
J. Kernohan proposed a grading system based on two microscopic features - anaplasia and mitotic activity. In 1988, St. Anne's Hospital team described modified grading by 4 microscopic criteria: nuclear atypia, mitosis, endothelial proliferation and necrosis (8). Similar grading system is also used in the latest World Health Organization (WHO) classification of CNS tumours. Glioblastoma is the highest grade (IV) of astrocytoma. Microvascular proliferation and/or necrosis (Fig.1) are essential for GBM diagnosis (17)

Several morphological variants of glioblastoma have been recognized (Table 1). Conventional GBM (Fig.2A) constitutes about $93 \%$ of all GBM. Less common nonconventional GBMs (Fig.2B-D) include gliosarcoma represented by biphasic tumour consisting from malignant glial and mesenchymal component, small cell GBM featuring small, round, relatively monomorphic cells with little amount of cytoplasm and giant cell GBM with extensive amount of highly pleomorphic giant cells (17). The prognostic significance of different GBM subtypes is limited. It is necessary to make a distinction between these entities because of the possible morphological overlap with neoplasms that have more favourable prognosis. A slightly better prognosis has been reported in patients with giant cell morphology, hypothetically due to better circumscription and greater resectability of this morphological subtype (27). Small cell glioblastoma has been described as aggressive GBM subtype. Due to nuclear and cell uniformity, small cell GBM can be easily misdiagnosed as anaplastic oligodendroglioma which has a more favourable prognosis (27). This subtype commonly has vague, small and sometimes incompletely developed foci of necrosis and microvascular proliferation embarrassing the diagnosis. Molecular testing can guide towards correct diagnosis. Small cell GBM is characterized by a high frequency of epidermal growth factor receptor (EGFR) gene amplification and exceedingly high proliferation rate. In contrast, $1 \mathrm{p} / 19 \mathrm{q}$ deletion specifically suggests diagnosis of anaplastic oligodendroglioma (27). 

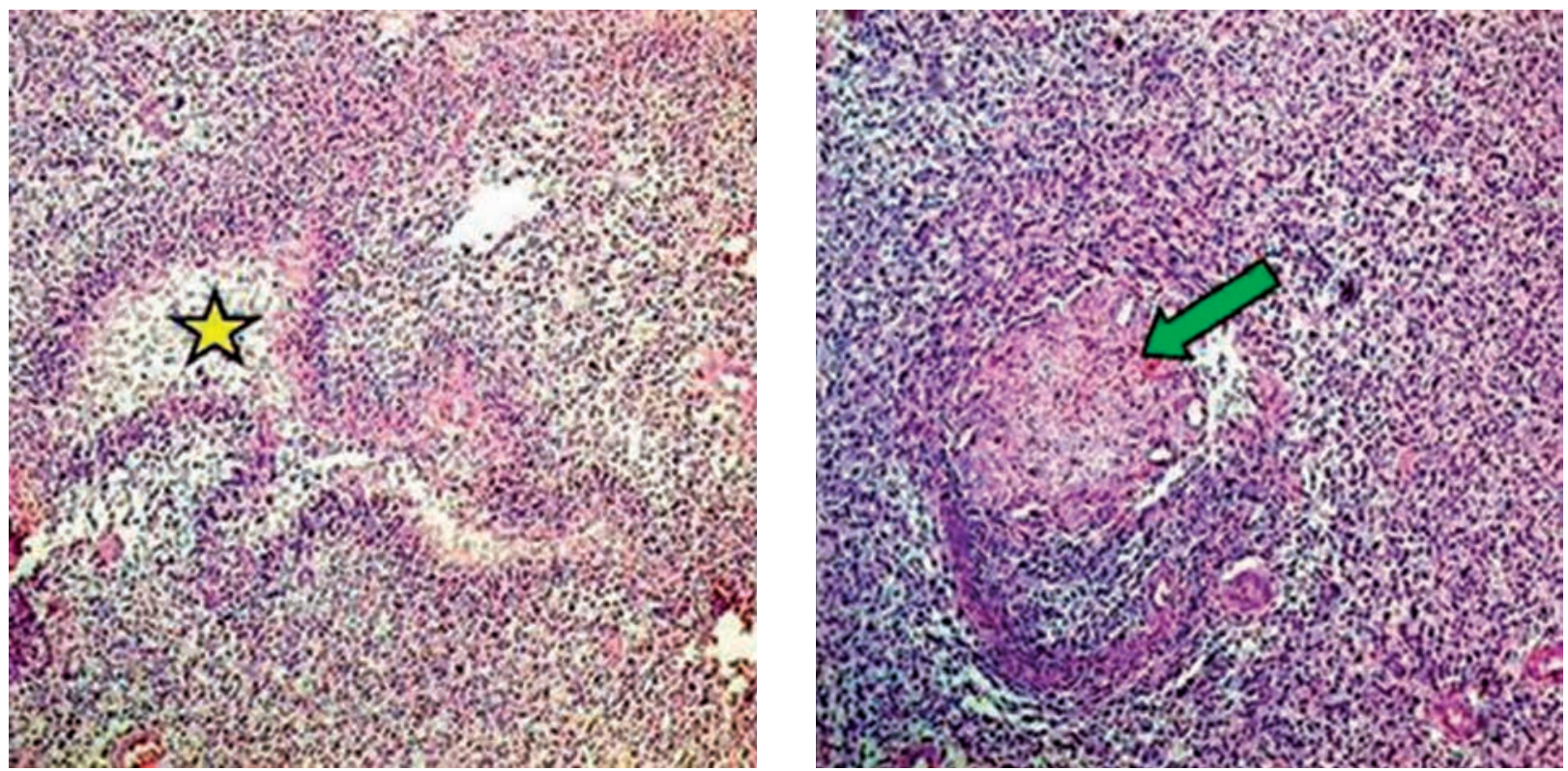

Fig. 1. Diagnostic criteria of glioblastoma. A, Pseudopalisading necrosis (yellow star). B, Microvascular proliferation (green arrow). All microphotograms: haematoxylin-eosin, original magnification 50x

Table 1. The most frequent histologic subtypes of glioblastoma (GBM)

\begin{tabular}{|l|l|l|l|}
\hline $\begin{array}{l}\text { Histologic } \\
\text { subtype }\end{array}$ & Frequency & Diagnostic features & Importance \\
\hline $\begin{array}{l}\text { Conventional } \\
\text { GBM }\end{array}$ & $93 \%$ & $\begin{array}{l}\text { Moderate to high pleomorphism. Prominent } \\
\text { necrosis and microvascular proliferation }\end{array}$ & $\begin{array}{l}\text { The most common type of } \\
\text { glioblastoma }\end{array}$ \\
\hline $\begin{array}{l}\text { Giant cell } \\
\text { GBM }\end{array}$ & $1-5 \%$ & $\begin{array}{l}\text { Very large, highly pleomorphic cells. Necrosis } \\
\text { and microvascular proliferation }\end{array}$ & $\begin{array}{l}\text { Not to be confused with low grade } \\
\text { pleomorphic xanthoastrocytoma } \\
\text { Slightly better prognosis }\end{array}$ \\
\hline Gliosarcoma & $2-8 \%$ & $\begin{array}{l}\text { Biphasic morphology: malignant glial and } \\
\text { mesenchymal component. Necrosis and } \\
\text { microvascular proliferation }\end{array}$ & No prognostic role \\
\hline $\begin{array}{l}\text { Small cell } \\
\text { GBM }\end{array}$ & Variable & $\begin{array}{l}\text { Monomorphic, round cells with little } \\
\text { cytoplasm, very high proliferation rate. } \\
\text { Necrosis and microvascular proliferation can } \\
\text { be poorly developed. In confusing cases, } \\
\text { detection of EGFR amplification, 10q and } \\
\text { lp/19q deletions is recommended. }\end{array}$ & $\begin{array}{l}\text { Anaplastic oligodendroglioma is } \\
\text { possible differential diagnosis }\end{array}$ \\
\hline
\end{tabular}

Molecular pathology of glioblastoma

Despite similar morphology, conventional GBMs show extensive heterogeneity both at cellular and molecular level. Tumours with similar histology can carry different molecular alterations and expression patterns which reflect distinct pathogenetic pathways and can have prognostic significance (17). Many attempts have been undertaken to identify robust molecular prognostic factors which bring data about pathogenesis of GBM, help to improve GBM management and even stratify this tumour into prognostic groups to make the therapy more personalized.
Single molecular prognostic markers of GBM

At present, few potential molecular prognostic markers for GBM are known. There are many controversies regarding their utility and the best way of testing in routine practice. Immunohistochemical visualization (IHC) is cheaper and simpler than molecular methods, thus the potential of IHC in testing of some most promising markers will be discussed.

O-6-methylguanine-DNA methyltransferase (MGMT). MGMT is one of the most evaluated prognostic and predictive markers. It has a potential to determine treatment response of temozolamide (TMZ) in GBM 

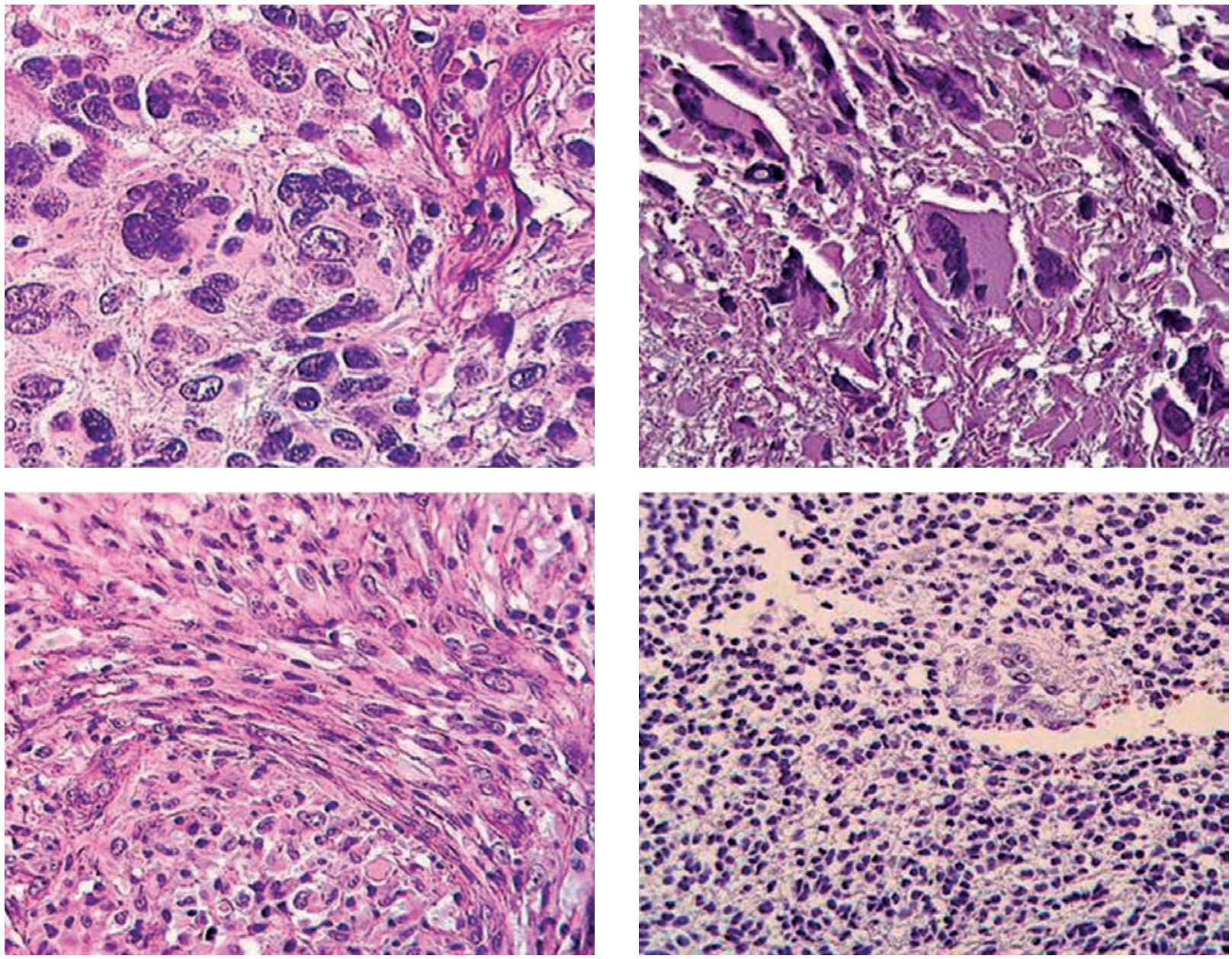

Fig. 2. Histologic subtypes of glioblastoma. A, Conventional glioblastoma. B, Giant cell glioblastoma. C, Gliosarcoma. D, Small cell glioblastoma. All microphotograms: haematoxylin-eosin, original magnification $100 x$

patients (11). TMZ is known as oral alkylating agent inducing DNA damage in tumour cells by methylating guanine residues in O-6 position. MGMT is DNA repair protein which can remove these methyl groups thus minimizing the effect of TMZ. In some tumours MGMT can be inactivated epigenetically by methylating $M G M T$ gene promoter. This prevents expression of MGMT protein and enhances the TMZ effect (32). There are many discussions regarding the best way of MGMT methylation testing. Methylation-specific polymerase chain reaction (MSP) has yielded most convincing clinical correlations $(32,11)$. The use of IHC for MGMT protein expression is controversial. Some of studies did not show clinical significance of anti-MGMT IHC (29). Other studies revealed that IHC analysis of MGMT can be used to predict the effects of chemotherapy (5). These discrepancies have been explained by high interobserver variability of interpreting IHC results (29), presence of non-neoplastic cells like activated microglia, tumour-associated macrophages which often express MGMT (20), and lack of correlation between MGMT gene methylation accessed by MSP and protein expression accessed by IHC (20).
Isocitrate dehydrogenase 1 (IDH1). IDH1 is a relatively new promising prognostic factor discovered only in 2008 by large-scale genomic analysis of GBM (25). IDHI mutations occur in almost all patients with secondary GBMs, mainly in young patients. It correlates with increased survival. Median overall survival rates of mutated and non-mutated IDHI patients are 3.8 and 1.1 years, respectively (25). The correlation between the presence of $I D H I$ mutation and survival is so impressive that some researchers suppose that primary GBMs with IDH1 mutation are under-diagnosed secondary GBMs and vice versa (12). The most frequent type of $I D H I$ mutation is IDHI R132H which results in formation of mutant protein. IHC for mutant IDHl $\mathrm{R} 132 \mathrm{H}$ protein is highly sensitive, reaching even $100 \%$ sensitivity and $100 \%$ specificity of IDH $\mathrm{R} 132 \mathrm{H}$ antibody against the mutation, verified by DNA sequencing (18). Thus routine IHC is perfect method to detect IDHI $\mathrm{R} 132 \mathrm{H}$ mutation and it can be used to differentiate between primary and secondary GBMs. Due to high frequency of IDHI R132H mutation in low-grade gliomas and absence in reactive astrogliosis, IHC can also be used in differentiation between these processes (4). 
CD133. There are many studies regarding stem cell role in GBM origin. It is thought that there is a small subpopulation of cancer cells with remarkable ability of self renewal, initiation and maintenance of cancer growth: tumour stem cells or tumour-initiating cells (TIC). CD 133 glycoprotein is one of the best known stem cell markers. One study showed that CD133 positive $(\mathrm{CD} 133+)$ cells isolated from glioma have an ability to initiate glial tumour in mice when transplanted, but CD133 negative (CD133-) cells lack this ability, suggesting CD133+ cell as TIC (31). CD133+ cells have been also shown to contribute chemoresistance in GBM thus promoting an idea of targeting these cells (16). Worse prognosis has been found in patients with increased number of CD133+ cells $(16,24)$. Correlation between CD133 and tumour grade and recurrence has also been reported (24). However, some studies failed to establish prognostic role of CD133+ cells (6). The theory of cancer stem cells is more complex than initially was thought and probably passes beyond the cells expressing CD133. It was found that CD133- population of cancer stem cells exists with similar features like CD133+ cells (3). These findings suggest that CD133 is not a universal marker for stem cell origin. Expression of CD133 can be modulated by hypoxia and cellular stress (7). CD133 may have some prognostic role and it can be easily detected by IHC, so further studies are needed.

Epidermal growth factor receptor (EGFR). Amplification of EGFR gene occurs in about $40 \%$ of GBM (23). The most common EGFR mutation leads to production of EGFRvIII protein which can be detected by IHC. The prognostic significance of wild-type EGFR and EGFRvIII protein expression in GBM is controversial. Some studies found correlation with survival in GBMs (30) while others rejected such association (35). One of studies found that EGFRvIII expression strongly correlated with prognosis only in anaplastic astrocytomas, but not in GBMs. The authors suggested that EGFRvIII can be used in identifying high grade gliomas whose clinical behaviour is consistent with that of GBM (1). Thus detection of EGFR amplification status is recommended for diagnostic purposes of GBM in cumbersome cases where tissue material is not fully representative or in differentiating between small cell GBM and anaplastic oligodendroglioma which commonly have overlapping features and highly different prognosis (27). Fluorescent in situ hybridization is the most accurate test for $E G F R$ amplification (10). EGFR amplification correlates with EGFR protein expression, but not in all cases. One study found expression of EGFRvIII detected by IHC in 41.3 $\%$ in GBM with EGFR amplification (35). So IHC can be used as a screening method. EGFRvIII is tumour specific protein, which can mark GBM cells and not normal cells (1). This finding inspired of possible targeting of EGFRvIII expressing GBMs. Latest promising therapy is vaccination against EGFRvIII protein (9). Other molecular markers with possible prognostic role like YLK-40 and CD44 have been also described $(26,36)$.

\section{Molecular subtypes of GBM}

For a long time, two GBM subtypes were known, reflecting different pathogenetic pathways: primary GBM which develop de novo and secondary GBM which results from progression from lower grade glial neoplasm (13). Nowadays, molecular investigations have shown so many molecular distinctions between these two subtypes that different diseases were suspected on the basis of their distinct genetic and clinical profiles $(13,23)$. Classical histopathological examination cannot distinguish these two subtypes.

A lot of research is directed towards elucidating the molecular and genetic basis of GBM. While investigations of individual gene or protein alterations can provide data on potentially important prognostic markers, new techniques like DNA microarrays allow to measure large numbers of genes and even expression profile of all tumour genome simultaneously.

The tumours that possess similar molecular signatures and expression patterns likely share common pathogenesis reflecting similar therapy responses and prognosis. So tumours can be stratified according to their common molecular signatures in different molecular subtypes among tumours that appear histologically indistinguishable but could carry different clinical outcomes. Five molecular subtypes of breast cancer is one of such successful examples where molecular subtyping has now been incorporated into the routine clinical practice. Extensive molecular analysis is highly expensive and time-consuming so its everyday application is limited. Immunohistochemical tumour profiling is alternative variant to transfer molecular data into routine practice.

Several high-throughput genetic studies in GBM patients have been published. GBM molecular subtypes have been identified recently $(34,28)$. The largest from these studies was carried out by The Cancer Genome Atlas project (TCGA) researchers. They found that all GBMs can be divided in 4 molecular subtypes: classical, mesenchymal, proneural, and neural subtypes characterized by different molecular alterations and gene expression patterns. The response to treatment also differed by the molecular subtype (Table 2). Different response to treatment in these subtypes was not associated with MGMT gene methylation status, thus GBM subtype seems to be independent therapy response predictor. Interestingly, these subtypes also expressed genes associated with certain types of brain cells (34). 
Table 2. Characteristics of the molecular subtypes of glioblastoma as described by The Cancer Genome Atlas project

\begin{tabular}{|l|l|l|l|}
\hline Subtype & Molecular changes & Clinical correlations & Cell type genetic signature \\
\hline $\begin{array}{l}\text { Proneural } \\
\text { subtype }\end{array}$ & $\begin{array}{l}\text { IDHI, TP53 and PDGFRA } \\
\text { mutations }\end{array}$ & $\begin{array}{l}\text { Better prognosis } \\
\text { Younger age } \\
\text { Resembles primary GBM } \\
\text { No benefit from combined treatment }\end{array}$ & Oligodendrocytic signature \\
\hline $\begin{array}{l}\text { Classical } \\
\text { subtype }\end{array}$ & $\begin{array}{l}\text { EGFR amplification } \\
\text { Frequent expression of mutant } \\
\text { EGFRvIII protein }\end{array}$ & $\begin{array}{l}\text { Expression of genes which are } \\
\text { mainly expressed in normal } \\
\text { neurons:NELF, GABRA and } \\
\text { others }\end{array}$ & Little potential benefit \\
\hline $\begin{array}{l}\text { Neural } \\
\text { subtype }\end{array}$ & $\begin{array}{l}\text { NF1 mutations } \\
\text { Expression of proteins that } \\
\text { are specific for mesenchymal } \\
\text { tissues: YKL-40 and MET. }\end{array}$ & Responds to treatment & $\begin{array}{l}\text { Astrocytic and } \\
\text { oligodendroglial signatures; } \\
\text { also normal neuron } \\
\text { signature }\end{array}$ \\
\hline $\begin{array}{l}\text { Mesen- } \\
\text { chymal } \\
\text { subtype }\end{array}$ & $\begin{array}{l}\text { Cultured astroglial cell and } \\
\text { mesenchymal signature }\end{array}$ \\
\hline
\end{tabular}

Another large study carried out by Phillips et al. classified GBMs into 3 subtypes: proneural, proliferative and mesenchymal (28). Proneural and mesenchymal subtypes showed close resemblance with corresponding TCGA subtypes. In contrast, the proliferative subtype was defined by over-expression of markers associated with proliferation. Proliferative subtype was characterized by significantly higher amount of Ki-67 positive tumour cells than proneural and mesenchymal GBM. However, mesenchymal GBM showed higher Ki-67 index in vasculature than other subtypes, consistent with higher expression of angiogenesis markers such as VEGF. GBM subtyping was also described in some smaller studies prior to these two mentioned above $(15,19,22)$. Liang et al. separated GBMs into 2 groups by expression of oligodendroglial markers: OLIG1 and OLIG2 (15). Mischel et al. divided GBMs in EGFR-over-expressing and EGFR-nonexpressing. These two subtypes showed different gene expression patterns (19). Nutt et al. showed that gene expression profiling correlated with survival better than histological classification (22).

GBM subtyping is possible and promising in routine practice but molecular data must be transformed in more simplified and cheaper approach for daily practice. There are few studies concerning this issue. Le Mercier et al. distinguished proneural-like and classical-like GBM subtypes based on IHC for only 3 proteins: EGFR, PDGFRA, and p53. They confirmed better survival in patients with proneural-like GBMs, whereas patients with classical-like GBMs showed better benefit from aggressive treatment. The authors suggested that markers such as NF1, YKL-40 and MET could be used to distinguish mesenchymal-like GBMs (14).

The extensive tumour heterogeneity remains challenging issue in molecular classification of GBM. Several molecular subtypes of GBM can coexist in one tumour, hypothetically due to different subpopulations of tumour cells with distinct responses to therapy (21).

\section{CONCLUSIONS}

While the awareness of GBM molecular biology is rapidly increasing, the prognosis for GBM is poor and no alternative treatment options exists. However, latest high-throughput molecular studies bring a ray of hope. New concept of molecular pathways, emerging molecular classification, new prognostic and predictive factors seem to be promising to improve treatment of GBM and make more personalized approach.

\section{Conflict of interest: None}

\section{REFERENCES}

1. Aldape KD, Ballman K, Furth A, Buckner JC, Giannini C, Burger PC, Scheithauer BW, Jenkins $\mathrm{RB}$, James CD. Immunohistochemical detection of EGFRvIII in high malignancy grade astrocytomas and evaluation of prognostic significance // J Neuropathol Exp Neurol, 2004; 63(7):700 - 707

2. Bailey PC, Cushing H. A classification of the tumors of the glioma group on a histogenetic basis with a correlated study of prognosis // Can Med Assoc J, $1926 ; 16: 872$

3. Beier D, Hau P, Proescholdt M, Lohmeier A, Wischhusen J, Oefner PJ, Aigner L, Brawanski A, Bogdahn U, Beier CP. CD133(+) and CD133() glioblastoma-derived cancer stem cells show differential growth characteristics and molecular profiles // Cancer Res, 2007; 67(9):4010 - 4015

4. Camelo-Piragua S, Jansen M, Ganguly A, Kim JC, Louis DN, Nutt CL. Mutant IDHl-specific immunohistochemistry distinguishes diffuse astrocytoma from astrocytosis // Acta Neuropathol, 2010; 119(4):509- 511

5. Capper D, Mittelbronn M, Meyermann R, Schittenhelm J. Pitfalls in the assessment of MGMT expression and in its correlation with survival in diffuse astrocytomas: proposal of a feasible immunohistochemical approach // Acta Neuropathol, 2008; 115(2):249 - 259 
6. Christensen K, Schroder HD, Kristensen BW. CD133 identifies perivascular niches in grade II-IV astrocytomas // J Neurooncol, 2008; 90(2):157 170

7. Griguer CE, Oliva CR, Gobin E, Marcorelles P, Benos DJ, Lancaster JR, Gillespie GY. CD133 is a marker of bioenergetic stress in human glioma // PLOS ONE, 2008; 3:11

8. Daumas-Duport C, Scheithauer B, O'Fallon J, Kelly P. Grading of astrocytomas. A simple and reproducible method // Cancer, 1988; 62:2152 2165

9. Del Vecchio CA, Li G, Wong AJ. Targeting EGF receptor variant III: tumor-specific peptide vaccination for malignant gliomas // Expert Rev Vaccines, 2012; 11(2):133-144

10. Fischer I, de la Cruz C, Rivera AL, Aldape K. Utility of chromogenic in situ hybridization (CISH) for detection of EGFR amplification in glioblastoma: comparison with fluorescence in situ hybridization (FISH) // Diagn Mol Pathol, 2008; 17(4):227 - 230

11. Hegi ME, Diserens AC, Gorlia T, Hamou MF, de Tribolet N, Weller M, Kros JM, Hainfellner JA, Mason W, Mariani L, Bromberg JE, Hau P, Mirimanoff RO, Cairncross JG, Janzer RC, Stupp R. MGMT gene silencing and benefit from temozolomide in glioblastoma // N Engl J Med, 2005; 352:997 - 1003

12. Kim W, Liau LM. IDH mutations in human glioma // Neurosurg Clin N Am, 2012; 23(3): 471 - 480

13. Kleihues P, Ohgaki H. Primary and secondary glioblastomas: from concepts to clinical diagnosis // Neuro Oncol, 1999; 1:44-51

14. Le Mercier M, Hastir D, Moles Lopez X, de Nève N, Maris C, Trepant AL, Rorive S, Decaestecker C, Salmon I. A simplified approach for the molecular classification of glioblastomas // PLoS ONE, 2012; $7: 9$

15. Liang Y, Diehn M, Watson N, Bollen AW, Aldape KD, Nicholas MK, Lamborn KR, Berger MS, Botstein D, Brown PO, Isral MA. Gene expression profiling reveals molecularly and clinically distinct subtypes of glioblastoma multiforme // Proc Natl Acad Sci U S A, 2005; 102 (16): 5814 - 5819

16. Liu G, Yuan X, Zeng Z, Tunici P, Ng H, Abdulkadir IR, Lu L, Irvin D, Black KL, Yu JS. Analysis of gene expression and chemoresistance of CD133+ cancer stem cell in glioblastoma // Mol Cancer, 2006; 5:67

17. Louis DN, Ohgaki H, Wiestler OD, Cavenee WK. Astrocytic tumors // Bosman FT, Jaffe ES, Lakhani RS, Ohgaki H. WHO classification of tumours of the central nervous system. $3^{\text {rd }}$ edition. Lyon: IARC, 2007; $13-52$

18. Loussouarn D, le Loupp AG, Frenel JS, Leclair F, von Deimling A, Aumont M, Martin S, Campone M, Denis MG. Comparison of immunohistochemistry, DNA sequencing and allele-specific PCR for detection of IDHI mutations in gliomas // Int J Oncol, 2012; 40(6):2058 - 2062

19. Mischel PS, Shai R, Shi T, Horvath S, Lu KV, Choe G, Seligson D, Kremen TJ, Palotie A, Liau LM,
Cloughesy TF, Nelson SF. Identification of molecular subtypes of glioblastoma by gene expression profiling // Oncogene, 2003; 22(15):2361 - 2373

20. Miyuki U, Mieko S, Oba S, Anamaria AC, Moura RP, Henrique PA, Navarro HC, Begnami M, Rosemberg S, Teixeira MJ, Nagahashi KS. Correlation of MGMT promoter methylation status with gene and protein expression levels in glioblastoma // Clinics (Sao Paulo), 2011; 66(10):1747 - 1755

21. Nicholas MK, Lukas RV, Chmura S, Yamini B, Lesniak M, Pytel P. Molecular heterogeneity in glioblastoma: therapeutic opportunities and challenges // Semin Oncol, 2011; 38(2):243 - 253

22. Nutt CL, Mani DR, Betensky RA, Tamayo $P$, Cairncross JG, Ladd C, Pohl U, Hartmann C, McLaughlin ME, Batchelor TT, Black PM, von Deimling A, Pomeroy SL, Golub TR, Louis DN. Gene expression-based classification of malignant gliomas correlates better with survival than histological classification // Cancer Res, 2003; 63(7):1602 - 1607

23. Ohgaki H, Kleihues P. Genetic pathways of primary and secondary glioblastoma. Am J Pathol, 2007; 170(5):1445 - 1453

24. Pallini R, Ricci-Vitiani L, Banna GL, Signore $M$, Lombardi D, Todaro M, Stassi G, Martini M, Maira G, Larocca LM, de Maria R. Cancer stem cell analysis and clinical outcome in patients with glioblastoma multiforme // Clin Cancer Res, 2008; 14:8205 8212

25. Parsons DW, Jones S, Zhang X, Lin JC, Leary RJ, Angenendt P, Mankoo P, Carter H, Siu IM, Gallia GL, Olivi A, McLendon R, Rasheed BA, Keir S, Nikolskaya T, Nikolsky Y, Busam DA, Tekleab H, Diaz LA Jr, Hartigan J, Smith DR, Strausberg RL, Marie SK, Shinjo SM, Yan H, Riggins GJ, Bigner DD, Karchin R, Papadopoulos N, Parmigiani G, Vogelstein B, Velculescu VE, Kinzler KW. An integrated genomic analysis of human glioblastoma multiforme // Science, 2008; 321(5897):1807 1812

26. Pelloski CE, Mahajan A, Maor M, Chang EL, Woo $\mathrm{S}$, Colman $\mathrm{H}$, Yang $\mathrm{H}$, Ledoux A, Blair $\mathrm{H}$, Passe $\mathrm{S}$, Jenkins RB, Aldape KD. YKL-40 expression is associated with poorer response to radiation and shorter overall survival in glioblastoma // Clin Cancer Res, 2005; 11:3326 - 3334

27. Perry A, Aldape KD, George DH, Burger PC. Small cell astrocytoma: an aggressive variant that is clinicopathologically and genetically distinct from anaplastic oligodendroglioma // Cancer, 2004; 101:2318 - 2326

28. Phillips HS, Kharbanda S, Chen R, Forrest WF, Soriano RH, Wu TD, Misra A, Nigro JM, Colman H, Soroceanu L, Williams PM, Modrusan Z, Feuerstein BG, Aldape K. Molecular subclasses of high-grade glioma predict prognosis, delineate a pattern of disease progression, and resemble stages in neurogenesis // Cancer Cell, 2006; 9(3):157 - 173 
29. Preusser M, Charles Janzer R, Felsberg J, Reifenberger G, Hamou MF, Diserens AC, Stupp R, Gorlia T, Marosi C, Heinzl H, Hainfellner JA, Hegi M. Anti-O6-methylguaninemethyltransferase (MGMT) immunohistochemistry in glioblastoma multiforme: observer variability and lack of association with patient survival impede its use as clinical biomarker // Brain Pathol, 2008; 18:520 532

30. Shinojima N, Tada K, Shiraishi S, Kamiryo T, Kochi M, Nakamura $H$, Makino $K$, Saya $H$, Hirano $H$, Kuratsu J, Oka K, Ishimaru Y, Ushio Y. Prognostic value of epidermal growth factor receptor in patients with glioblastoma multiforme // Cancer Res, 2003, 63:6962-6970

31. Singh SK, Hawkins C, Clarke ID, Squire JA, Bayani J, Hide T, Henkelman RM, Cusimano MD, Dirks PB. Identification of human brain tumour initiating cells // Nature, 2004; 432(7015):396 - 401

32. Soejima H, Zhao W, Mukai T. Epigenetic silencing of the MGMT gene in cancer // Biochem Cell Biol, 2005; 83(4):429 - 437

33. Stupp R, Mason WP, van den Bent MJ, Weller M, Fisher B, Taphoorn MJ, Belanger K, Brandes AA, Marosi C, Bogdahn U, Curschmann J, Janzer RC, Ludwin SK, Gorlia T, Allgeier A, Lacombe D, Cairncross JG, Eisenhauer E, Mirimanoff RO; European Organisation for Research and Treatment of Cancer Brain Tumor and Radiotherapy Groups; National Cancer Institute of Canada Clinical Trials Group. Radiotherapy plus concomitant and adjuvant temozolomide for glioblastoma // N Engl J Med, 2005; 352:987 - 996
34. Verhaak RG, Hoadley KA, Purdom E, Wang V, Qi Y, Wilkerson MD, Miller CR, Ding L, Golub T, Mesirov JP, Alexe G, Lawrence M, O'Kelly M, Tamayo P, Weir BA, Gabriel S, Winckler W, Gupta S, Jakkula L, Feiler HS, Hodgson JG, James CD, Sarkaria JN, Brennan C, Kahn A, Spellman PT, Wilson RK, Speed T, Gray JW, Meyerson M, Getz G, Perou CM, Hayes DN. An integrated genomic analysis identifies clinically relevant subtypes of glioblastoma characterized by abnormalities in PDGFRA, IDH1, EGFR and NF1 // Cancer Cell, 2010; 17(1):98 - 110

35. Viana-Pereira M, Lopes JM, Little S, Milanezi $F$, Basto D, Pardal F, Jones C, Reis RM. Analysis of EGFR overexpression, EGFR gene amplification and the EGFRvIII mutation in Portuguese high-grade gliomas // Anticancer Res, 2008; 28(2):913 - 920

36. Wei KC, Huang CY, Chen PY, Feng LY, Wu TW, Chen SM, Tsai HC, Lu YJ, Tsang NM, Tseng CK, Pai PC, Shin JW. Evaluation of the prognostic value of CD44 in glioblastoma multiforme // Anticancer Res, 2010; 30(1):253-259

\section{Address:}

Arvids Jakovlevs,

Department of Pathology,

Riga Stradins University

Dzirciema Street 16,

Riga, LV-1007, Latvia

E-mail: Arvids.Jakovlevs@rsu.lv 